serrated edge of a graduated disk or dial, one revolution of which marks Ioo revolutions of the stirrer. The stirrer is suspended so that its bottom is $3 / 8$ inch above the bottom of the cup, and in consequence its top is $3 /{ }_{4}$ inch below the top of the same; when in use the cup is filled to within $3 / 8$ inch of its top with liquid which, therefore, stands $3 / 8$ inch above the top of the stirrer. To make a hundred revolutions of the stirrer the weight descends about 39 inches. The stirrer comes within $1 /{ }_{16}$ inch of each side of the radial wings, one on each side of the cup, already mentioned.

The index of viscosity may be defined as the force required to produce a given shear in a given time; if we adopt a minute as the unit of time, and the shear produced by roo revolutions of the stirrer as the unit shear, the viscosity will be indicated by the number of grams (units of weight) required to cause the stirrer to revolve roo times in one minute. A1lowance should be made for the friction of the machine, which in this instrument is about 5 grams.

It has a friction clutch which, being opened, allows it to start; it is used with a stop-watch. As at present sold it is not provided with a suitable scale-pan and weights, but is supposed to be used with a fixed weight, which is sufficient if we wish only to bring various mixtures to one standard, but is like using a fixed measure instead of a scale. It is very important to use it at a standard temperature.

LABORATORY OF INDUSTRIAL CHEMISTRY, PRATt INSTITUTE, BROOKLYN.

\section{A STUDY OF CARBON IN SEWAGE AND SEWAGE PURIFICATION.}

By H. W. Clark and George O. Adams. 1 Received June, 11911.

The part that nitrogen plays in sewage and sewage purification and in the analysis of sewage and water is well known to all engaged in sanitary work that has to do with water and sewage or their purification. The important part played by carbon and carbonaceous matter is, however, not so well understood; neither is the relation that carbon bears to nitrogen in the composition of sewage and water, in analytical work and in sewage purification, fully comprehended. Carbon, however, is the chief constituent of the organic matter in sewage and is a troublesome factor in the satisfactory disposal of sewage. It is carbonaceous matter, moreover, that gives color and other objectionable characteristics to some water supplies. To such sanitary chemists and engineers as construct, operate or study sewage plants, sewage filters, etc., the problem of carbon disposal appears more and more important. This is especially true when industrial sewage is to be treated. For a more complete understanding of that portion of the problem of sewage purification that has to do with carbon, studies have been made at the Lawrence Experiment Station from time to time during the past ten years in regard to the amount of carbon in sewage and water; the relation that carbon in samples undergoing analysis bears to the results of loss on ignition and oxygen

1 Lawrence Experiment Station, Mass. State Board of Health. consumed determinations and to other bodies that may be determined by the analysis of sewage and water, and of the work accomplished by various classes of sewage filters in caring for the purely carbonaceous bodies in the sewage applied to them. In various reports of the Experiment Station during the past seven or eight years, much data accumulated in these studies have been given. In this work as elaborated in the reports, many comparisons have been made between the amount of nitrogen and carbon in the samples analyzed and the relative amount of oxygen necessary to oxidize the carbon compounds as compared with the amount necessary to oxidize the nitrogenous bodies in sewage.

The following paper presenting a summary of much of this carbon work, together with the results of additional studies, can be properly divided into several sections. Between some of these sections there may not seem to be any very clearly defined relation, but all have to do with carbon, nitrogen and oxygen in sewage and its purification.

(I) No. I deals with the determinations of the actual amount of carbon in samples of sewage and water and gives a comparison of the amount of this carbon with the amount of organic and other matter determined by the loss on ignition process; (2) No. 2 is in regard to relative amounts of carbon and nitrogen in sewage; (3) No. 3 deals with the relation between carbon and fatty matters in sewages; (4) No. 4 compares the per cent. that carbon forms of the loss on ignition determinations when sands from sewage filters that have been in operation are examined; (5) No. 5 gives the results of a series of studies of the oxygen consumed process, so-called, and what it shows in regard to carbonaceous and nitrogenous matter in water and sewage; (6) No. 6 treats of the relation between the amount of each oxidized or stored in such filters; and (7) N. 7 treats of the influence of carbon on nitrification.

CHAPTER NO. I.-COMPARISON OF CARBON AND LOSS ON IGNITION.

In order to determine and show the amount of carbon in average samples of sewage and water and the relation between carbon and loss on ignition, dry residues from the evaporation of forty-four samples of sewages, waters, etc., were obtained. These samples were as follows: Tweive samples of sewage and ten of the same samples after filtration through paper, nine samples of surface waters, three of well waters, five effluents from sand filters which had received sewage for many years, three effluents from trickling sewage filters operating at a high rate and two mill wastes, both unfiltered and filtered through paper. In obtaining these dry residues for analysis, the following precautions were taken: First, dust was carefully excluded during evaporation; second, the alkalinity of each sample was neutralized to avoid error in the final results due to the decomposition of carbonates during the combustion for the determinations of carbon, and an allowance was made for the decrease in weight of the residue due to neutralizing the carbonates. Carbon combustions were made by 
the usual method and to prevent the red fumes of nitrogen oxide evolved from being absorbed in the potash bulbs, a Geissler bulb filled with strong sulphuric acid was placed between the calcium chloride tubes and the potash bulb, and all but a slight trace of the nitrogen oxide thus absorbed, this precaution being necessary only with the residues of samples high in nitrates. The analyses of the sewage residues showed that carbon formed as an average 23 per cent. of the total residues and 50 per cent. of the total loss on ignition when loss on ignition was determined in the usual way.

Of the residue from the evaporation of surface waters, 7.5 per cent. proved to be carbon and, as an average, 26 per cent. of the total loss on ignition was carbon. Of the residues from the evaporation of the effluents from the sewage filters of coarse material, previously mentioned, Io per cent. was carbon, and the average amount that the carbon in these residues was of loss on ignition was 36 per cent. It is of course true that most, if not all, of the organic compounds likely to be found in sewage have percentages of carbon varying nearly within these limits. Carbohydrates contain from 40 to 44 per cent. of carbon, albuminous bodies from 50 to 55 per cent. and such fats as we have separated from sewage, 62 per cent. Studying these averages it is seen that while "loss on ignition" is undoubtedly, as is generally believed, a fair measure of the organic matter present in samples of sewage and water, yet it does not, of course, bear a very constant relation to the per cent. of carbon present.

It might, perhaps, be mentioned here that if the samples undergoing ignition contain nitrates, the loss of nitrogen during ignition, due to the reduction of these nitrates, is considerable. To illustrate this, nine residues of effluents from sewage filters ignited in the usual way in a platinum radiator, lost on an average $\mathrm{I} .23$ parts of nitric nitrogen for each part of "oxygen consumed" shown by the sample. If each part of nitric nitrogen is equivalent to 4.3 parts $\mathrm{N}_{2} \mathrm{O}_{5}$, this loss is considerable when nitrates and oxygen consumed are both high, as is often the case in the effluents from sewage filters of coarse materials.

Table Showing the Amounts of Carbon in Waters, Sewages, etc

Per cent Per cent. carbon in Carbon. carbon in volatile Parts residue on matter. per evapora- (Loss on

Sample.

100,000 .

tion.

ignition.)

Average of 12 samples of sewage:

Unfiltered............... $19.7 \quad 22.8 \quad 50$

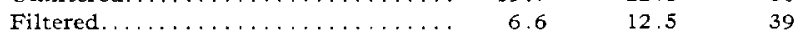

Average of 3 samples from contact and trickling filters:

Infiltered ................ 7.0

Filtered.............

Average of 5 samples from sand sewage

filters.....................

Average of 9 samples of surface waters.

Average of 3 samples of ground waters.

Wool scourings, unfiltered........... 98.3

Wool scourings, filtered............ 45.4

Paper mill waste, unfiftered . . . . . . 136.2

Paper mill waste, filtered.

136.2
8.5

${ }^{1}$ Low, due to loss of nitrates during ignition
COMPARISON OF NITROGEN AND CARBON.

The following table presents a comparison of the relative amount of nitrogen and carbon in the samples already discussed. It will be noticed that in the sewages the carbon averages more than five and onehalf times the organic nitrogen and three and one-half times the total nitrogen. The other figures are equally interesting, especially those of the two mill wastes presented; namely, wool-scouring and japer mill wastes, for in these the carbon was respectively twentyone and fourteen and one-half times the organic nitrogen. It will be noticed also that the carbon present in the samples of surface and ground waters was from sixteen to twenty times as great as the nitrogen present.

Table Showing Relation between Carbon ayd Nitrogen in Waters, SEWAGES, ETC

Racio of Ratio of Kjeldahl total Parts Parts nitrogen $N$ to

Parts Kjeldahl total to carbon carbon

Average of 12 samples of sew-

age:

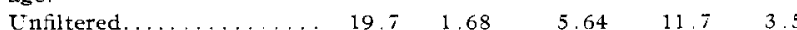

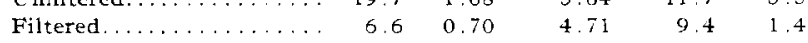

Average of 3 samples from con-

tact and trickling filters:

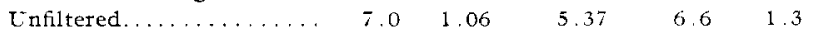

Filtered............. $2.6 \quad 0.35 \quad 3.16 \quad 7.3 \quad 0.81$

Average of 5 samples from

sand sewage filters.......

Average of 9 samples of sur-

Average of 3 samples of ground

waters............ $0.33 \quad 0.016 \quad 0.120 \quad 20.5 \quad 2.7$

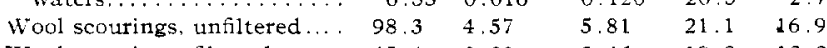

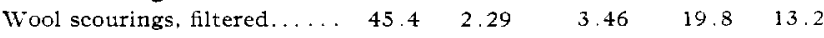

$\begin{array}{llllll}\text { Paper tnill waste, unfiltered. . } & 136.2 & 9.31 & 10.30 & 14.6 & 13.2\end{array}$

$\begin{array}{rrrrrr}\text { Paper mill waste, filtered. . . . } & 8.5 & 0.55 & 0.65 & 15.5 & 13.1\end{array}$

\section{CARBON, LOSS ON IGNITION AND FATS.}

In determining the organic matter in sludges and sediments high in organic matter, the probable errors due to chemically combined water, mentioned on subsequent pages, are relatively small because the organic matter may be a hundred or more times greater than any loss of chemically combined water, while with the sands, figures in regard to which are given later, the organic matter is frequently much less than the amount of chemically combined water. Results of analyses for the determination of carbon and organic matter determined by "loss on ignition" of sludges and sediments are shown in a following table. The table shows that one-half of the organic matter in certain sewage sludges is fatty matter; and it will be seen that the carbon present in the sludge of fresh sewage is approximately 55 per cent. of the loss on ignition, and in trickling filter or contact filter sediments, 5o per cent. of the loss on ignition. In septic sewage sludge, the percentage of carbon is apparently a little higher, varying from 56 per cent. to $6 \mathrm{I}$ per cent. About 35 per cent. of the total carbon is represented by the carbon of the fats present in fresh sewage, while in septic sewage the carbon of the fats is about 25 per cent. of the total carbon. 
Table Showing Amounts and Composition of Organic Matter in Sewage Siudges and iN Sedments from Filters of Coarse Material. Per cent. Per cent. loss on Per cent. Kjeldahl . Per cent.

Sample.

ignition. carbon. nitrogen. fats.

Average of 4 fresh Lawrence sewage sludges..........

Average of 12 Andover sewage

sludges............. 48.4

Average of 4 septic tank sludges 49.1

Average of 9 sediments from

sewage filters of coarse ma-

nitrogen.

$$
37.3
$$

$27.1 \quad 1.49$

24.9

28.8

$\cdots$

19.9

11.3

21.3

1.78 terial............. 42.9 Preceding Table.

\begin{tabular}{|c|c|c|c|c|}
\hline Sample, & $\begin{array}{l}\text { Per cent. } \\
\text { carbon is } \\
\text { of loss } \\
\text { on } \\
\text { ignition. }\end{array}$ & $\begin{array}{l}\text { Per cent. } \\
\text { fats are } \\
\text { of loss } \\
\text { on } \\
\text { ignition. }\end{array}$ & $\begin{array}{l}\text { Per cent. } \\
\text { carbon in } \\
\text { fats is } \\
\text { of total }\end{array}$ & $\begin{array}{l}\text { Ratio of } \\
\text { carbon } \\
\text { to } \\
\text { K jeldahl }\end{array}$ \\
\hline $\begin{array}{r}\text { Average of } 4 \text { fresh Lawrence } \\
\text { sewage sludges............. } \\
\text { Average of } 12 \text { Andover sewage }\end{array}$ & 55.8 & 37.2 & 41.4 & \\
\hline sludges $\ldots \ldots \ldots \ldots \ldots \ldots$ & 56.0 & 41.1 & 45.5 & 18.2 \\
\hline $\begin{array}{l}\text { Average of } 4 \text { septic tank sludges } \\
\text { Average of } 9 \text { sediments from } \\
\text { sewage filters of coarse ma- } \\
\text { terial................... }\end{array}$ & 58.7 & 23.0 & 24.3 & $\ldots$ \\
\hline
\end{tabular}

CARBON AND LOSS ON IGNITION-SANDS.

In estimating the amount of organic matter present in sands by the loss on ignition of such sands, there is a large error due to the loss of chemically combined water during ignition. This loss may even be I per cent. of the total weight of the samples taken, when the sand is clean, although it is usually lower. In order to determine how much of the loss on ignition in clean sands is due to organic matter and how much to chemically combined water, combustions were made on two clean sands, and these results are given in the following table:

TAble Showing Results of Combustions of Two Clean sands.

$\begin{array}{ccc}\text { Number. } \quad \begin{array}{c}\text { Per cent. loss } \\ \text { on ignition. }\end{array} & \begin{array}{c}\text { Per cent. } \\ \text { carbon. }\end{array} & \begin{array}{c}\text { Per cent. } \mathrm{H}_{2} \mathrm{O} \\ \text { recovered. }\end{array} \\ 1 \ldots \ldots \ldots \ldots, 0.32 & 0.000 & 0.33 \\ 2 \ldots \ldots \ldots, 0.33 & 0.015 & 0.32\end{array}$

The table shows that the carbon results average about 35 per cent. of the loss on ignition results and the carbon found in these sands was from seven to twelve times as great as the organic nitrogen that was found. Analyses of other sands follow:

Tarle showing Relation between Carbon, Nitrogen and Organic MatTeR STOREd IN SANdS.

Per cent.

that Ratio of carbon

carbon

is of Per cent

Loss on

ignition. Carbon. loss on of nitro- Kjeldahl Total
Sample. Per cent. Per cent. ignition. gen. nitrogen. nitrogen

Filter No. I sand:

Average 3 inches

Average 9 inches
Average 12 inches

$2.16 \quad 0.947$

43.8

$0.08 \quad 11.55$

Filter No. 6 sand:

Average 3 inches

Average 6 inches

$1.75 \quad 0.648$

37.0

0.10

6.29

31.5

0.05

7.18

$\cdots$

$3.26 \quad 1.091$

33.5

$0.12 \quad 8.78$

Average 9 inches

$3.14 \quad 1.083$

34.5

0.11

10.00

Filter No. 9 sand:

Average 3 inches $\quad 2.56 \quad 0.992$

38.5

$0.10 \quad 11.80$

Average 6 inches

$\begin{array}{ll}2.84 & 0.987\end{array}$

38.8
36.4

$0.08 \quad 11.50$

Average 9 inches

$2.16 \quad 0.521$

Regular sewage........ . . .

Lawrence Street sew-

$0.07 \quad 7.56$

age................

$\ldots \ldots$

...

... 10.40

$\ldots \quad \ldots \quad 15.60$

... $\ldots: \quad 7.10$
OXYGEN CONSUMED.

It is well known that the "oxygen consumed" determination indicates only a portion of the organic carbon present in the water or sewage tested by this method and that that portion is not a constant; also that the "loss on ignition" determination includes some mineral as well as the organic matter present. The following figures show the percentage which the "oxygen consumed" obtained in the usual way (by five-minute acid-boiling) is of the oxygen actually required to oxidize the carbon in the following substances, these figures being determined by careful laboratory tests: With saccharose, 24 per cent.; dextrose, 22 per cent.; starch 0.17 per cent.; lactose, 9.6 per cent.; cellulose, 0.13 per cent.; and peptone, 5.7 per cent. Somewhat higher percentages are obtained when the process is applied to sewage, etc., this probably being due to the breaking down of complex bodies into simple and less stable compounds. On page 366 of the "Massachusetts State Board of Health Report for 1905," comparisons of two-minute, five-minute and thirty-pinute boiling of samples with permanganate, or "oxygen consumed" results, are given. In this work oxygen consumed by both two- and five-minute boiling was determined on over six hundred samples of various kinds of water, sewage and effluents. The results by the two-minute method averaged for each class of water between 70 and 80 per cent. as high as the results by the five-minute method.

In further work, the "oxygen consumed" of thirtysix samples of sewage was determined by two-minute boiling and by heating in a boiling water bath for thirty minutes. As an average, the two-minute results were 55.5 per cent. of the thirty-minute results. In the samples in which carbon was determined, the heating with permanganate was continued until a maximum result was obtained. The samples were heated in free-flowing steam in an Arnold steam sterilizer. Usually eight hours were sufficient. Averaging all the samples, the results by the two-minute method were shown to be 33.8 per cent. of the maximum results.

From the known content of carbor in each sample, the oxygen required to oxidize it was calculated together with the per cent. which the "oxygen consumed" by the two-minute method and maximum methods were of this required carbon. In unfiltered sewages, the two-minute "oxygen consumed" was from ro to 19 , and the maximum "oxygen consumed" was from 34 to 54 per cent. of the oxygen actually required to oxidize the carbon. In the filtered sewages, higher percentages were obtained on account of absence of cellulose and these percentages were from I 3 to 28 for the two-minute and for the maximum, from 5 I to 86 per cent. of the oxygen actually required to oxidize the carbon. In the samples of effluents and waters, the percentages ran higher.

The following table presents some results of oxygen consumed tests upon the samples of sewage, water and wastes previousiy discussed in comparison with carbon and nitrogen. 
"Aale Showing Relation between "Oxygen Constmed" and the AMOUNT OH CARBON in WATERS, SEWAGES, ETC,

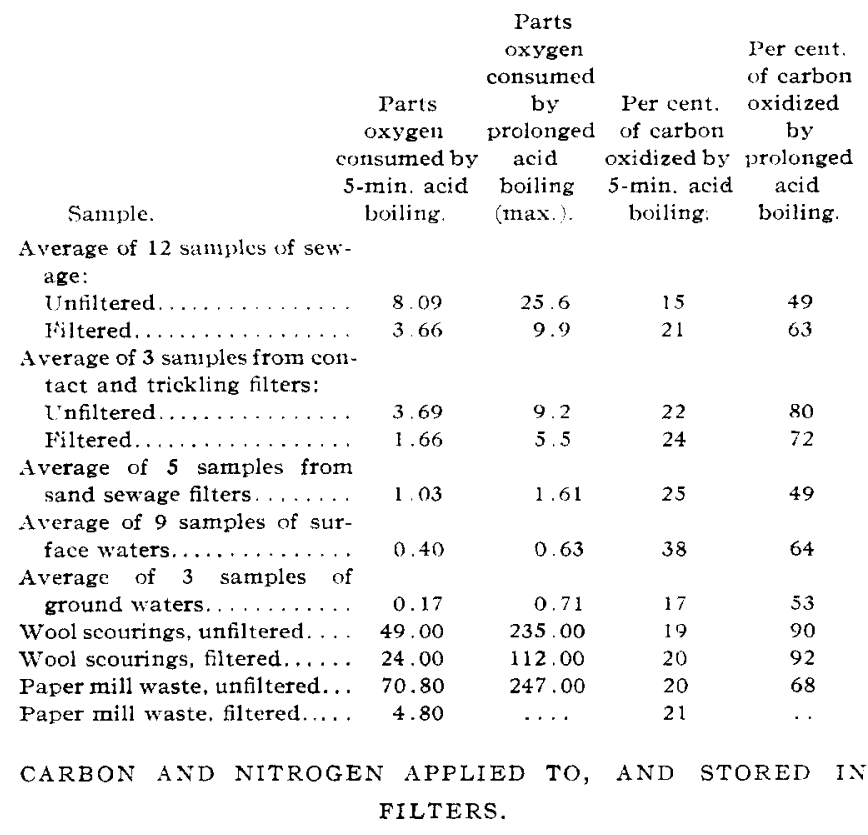

The preceding tables show that the amount of carbon in sewage is from ten to fifteen.times the organic nitrogen usually present. A considerabe part of this carbon is present as cellulose and fats, of which the cellulose is especially stable, and it is these bodies which are chiefly responsible for the clogging of sewage filters. The following table shows the relation between the amounts of organic nitrogen and carbon applied to, stored in certain sewage filters, liberated or passing off in the effluents. A study of this table makes clear the very large amount of carbon applied as compared with organic nitrogen applied-about ten pounds of carbon to each pound of organic nitrogen. About seven times as much carbon as nitrogen is stored, as shown by the figures in the table.

\begin{tabular}{|c|c|c|c|c|}
\hline & Filter A. & Filter B. & Filter C. & Filter D. \\
\hline Period of operation (months). & 72 & 72 & 31 & 23 \\
\hline \multicolumn{5}{|l|}{ Pounds per acre, applied: } \\
\hline Kjeldahl nitrogen. $\ldots \ldots \ldots$ & 226,200 & 210,700 & 45,800 & 65,900 \\
\hline Carbon $\ldots \ldots \ldots \ldots \ldots$ & $2,511,000$ & $2,390,000$ & 413,000 & 593,300 \\
\hline \multicolumn{5}{|l|}{ Founds per acre, in effluent: } \\
\hline Kjeldahl nitrogen. . . . . . . & 76,500 & 88,140 & 15,580 & 30,640 \\
\hline 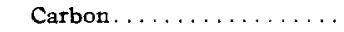 & 566,100 & 652,200 & 90,400 & 226,800 \\
\hline \multicolumn{5}{|l|}{ Pounds per acre, stored: } \\
\hline Kjeldahl nitrogen. . . . . . . . & 10,390 & 12,600 & 16,500 & 18,670 \\
\hline Carbon. . . . . . . . . . & 73,940 & 82,680 & 126,500 & 112,400 \\
\hline \multicolumn{5}{|l|}{ Per cent. in effluent: } \\
\hline Kjeldahl nitrogen $\ldots \ldots \ldots$ & 33.8 & 41.8 & 34.0 & 51.7 \\
\hline Carbon. . . . . . . . & 22.5 & 27.3 & 21.9 & 38,2 \\
\hline \multicolumn{5}{|l|}{ Per cent. stored: } \\
\hline Kjeldahl nitrogen $\ldots \ldots \ldots \ldots$ & 4.6 & 6.0 & 36.0 & 31.5 \\
\hline Carbon. . . . . . . . . . & 2.6 & 3.5 & 35.4 & 18.9 \\
\hline \multicolumn{5}{|l|}{$\begin{array}{l}\text { Per cent oxidized and liber- } \\
\text { ated: }\end{array}$} \\
\hline a........ & 61.6 & 52.2 & 30.0 & 16.8 \\
\hline Carbon, ............... & 74.6 & 69.2 & 42.7 & 42.9 \\
\hline
\end{tabular}

ORGANIC MATTER IN SAND FILTERS.

The discussion and analytical figures already given show very plainly that purely carbonaceous matter forms by far the larger portion of the organic matter which we have to deal with in sewage and sewage purification. The percentage of nitrogen is small in the organic matter present in sewage and stored in filters. The reason that it has so prominent a place in all studies of water and sewage is that it is the chief constituent of matter that is easily changed, and its change from one form or combination to another shows clearly the transformation of a polluted liquid to a well purified liquid, and the analyses of the different combinations of. nitrogen are necessary to show the composition of sewage and the purification taking place in filters, etc. The clogging which occurs in sand and other filters is mainly due, however, to carbon and fatty matters. If we take as a study three sand filters of fairly coarse sand which have been longest in operation at the Lawrence Experiment Stationat the present time this period of operation covering twenty-three years-we find by analysis of the sand of these filters that the stored nitrogen forms but about 4 or 5 per cent. of the total organic matters now retained by the sand, the remaining 96 per cent. being largely carbonaceous organic matter such as cellulose, fats, etc. The figures for stored matter in the three filters mentioned are as follows:

$\begin{array}{ccc}\text { Filter No. } & \text { Stored nitrogen } & \begin{array}{l}\text { Total urganic matter stored } \\ \text { diring period of operation. }\end{array} \\ 1 & 27 \text { pounds } & 783 \text { pounds } \\ 6 & 31 \text { pounds } & 618 \text { pounds } \\ 9 \mathrm{~A} & 29 \text { pounds } & 590 \text { pounds }\end{array}$

Accurate determinations of the carbonaceous constituents of the organic matter stored in these three filters have been made by combustion furnace analyses, and the following tables give the amounts of carbon, and for purposes of comparison, determinations of organic matter by the loss on ignition method. As has been explained previously in this article, the loss on ignition gives figures that are high, and the total loss is not entirely organic matter, as is, of course, well known. The tables show that at least 75 per cent. of the stored carbonaceous matters are in the first foot in depth of each filter.

Table Showing amolnt of Carbon, in Pounds per ACre per foot of SAND, IN FILTERS NOS. 1,6 AND 9A.

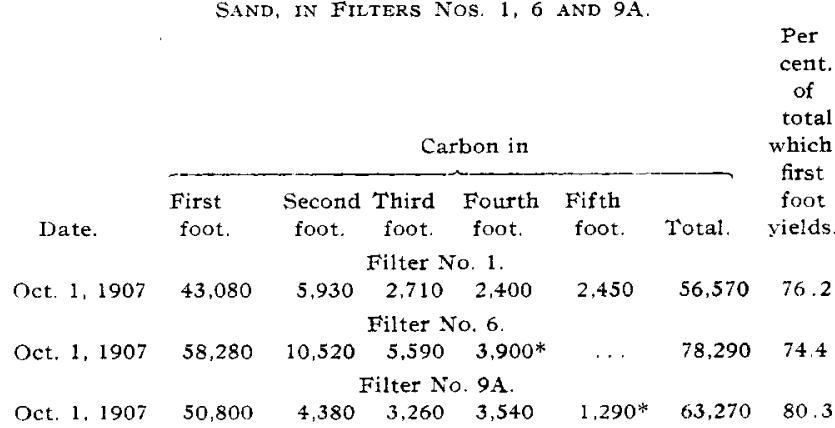

Total Organic Matter Stored, in Pounds per acre per Foot of sand. in Large Filters, as Determinien by loss on ignitjon, Correcter For ORGANic MatTEK in ORIGINAL SAND.

Jilter $\mathrm{No} .1$

July $1,1908 \quad 104,520 \quad 21,800 \quad 11,100 \quad 5,800 \quad 13,340 \quad 156,560 \quad 66.7$ Filter No. 6.

July $1,1908 \quad 106,260$ $\begin{array}{ccc}4,620 \quad \ldots & 15,920 \\ \text { Filter No. } 91 . \\ 8,780 \quad 840 \quad 420\end{array}$ $126,800 \quad 83.8$

July $1,1908 \quad 107,140$ $\begin{array}{llllll}8.780 & 840 & 420 & 7,200 & 124,380 & 86.2\end{array}$

* Six inches only. 
INFLUENCE OF CARBON UPON NITRIFICATION.

During the past fifteen years a large number of investigations have been made at the Station and elsewhere in the state in regard to methods for the disposal and purification of waste liquors from various industrial plants. During these studies certain results were obtained that caused us to believe that the activity of the nitrifying organism and the formation of nitrates were probably dependent upon the relation of carbon to nitrogen in the wastes studied. In order to determine whether or not this belief was true, a large number of special experiments are being made by us, and while not yet complete, the results so far obtained show that the carbon does have the influence that our observations seemed to show. A sewage or waste containing, say, $x$ amount of nitrogen will, when submitted to oxidizing or nitrifying conditions in a filter, fail to nitrify if there is an amount of carbon equal to rox. Increasing the amount of nitrogen, however, will enable nitrification to take place, but this nitrification may again be checked by increasing the carbon. The results of the various investigations along this line will be presented in a subsequent paper.

State Board of Health, Boston.

COMPOSITION OF THE DRAINAGE WATER OF A SOIL WITH AND WITHOUT VEGETATION.

By LytTLETON Lyon AND JAMES A. BizzetL Received July 20, 1911

Drainage water was collected from twelve large tanks, a description of which has previously been published. $^{r}$ Each tank is slightly over four feet square and four feet deep with a capacity for about three and one-half tons of soil. They receive the natural rainfall but no other supply of moisture. Twelve tanks were filled with clay loam soil of uniform character in 1909 and crops were raised on certain of the tanks in igro. The drainage water was meas- and also the drainage between October $I$, Igro, and May I, I9I I

It is probable that the composition of the drainage water does not at present correspond exactly to that of the soil in the field. Monthly analyses of drainage from two of the plats show a gradual reduction in the concentration of the solution. The soil was well compacted when placed in the tanks, each horizontal foot being packed in the tanks in the relative position which it occupied in the field. As there has been almost no settling of the soil since these receptacles were filled, it is probable that no abnormal aeration is now taking place. The effect of plant growth during the summer of I 9 Io on the density and composition of the drainage water collected between Oct. I, IgIo, and May I, I9II, is very apparent, when the flow from the unplanted tanks is compared with that from the tanks on which plants were raised. Owing to the fact that, of the drainage collected between May 23 and Oct. I, a very small proportion was collected after the plants began to grow vigorously, this liquid does not show so markedly the effect of plant growth on the soluble matter of the soils.

Three tanks contained no plants, four were planted to maize and two to oats.

A statement of the average flow of drainage water by months from tanks unplanted, planted to maize and planted to oats is given in Table I. Both the maize and oat tanks were planted on May 23, the date on which the measurement of the flow of drainage began. Oats ripened about Aug. 7 th and maize continued to grow until the latter part of September. The growth of the crops did not curtail the flow of drainage until July and even then the dry weather reduced the flow from the unplanted tanks practically as much as from the planted. The removal of water from the soil by the plant did not influence the flow of drainage until September and from then until

Table I. - Flow of Drainage Water (in Liters) from the Average Tank when Unplanted; when Planted to Maize and when Planted to Oats

\begin{tabular}{|c|c|c|c|c|c|c|c|c|c|c|c|c|c|c|c|}
\hline rank Nos. & Crop. & $\begin{array}{c}\text { May } 23 \\
\text { to } \\
\text { June } 1 .\end{array}$ & June. & July. & Aug. & Sept. & Oet. & Nov. & Dec. & Jan. & Feb. & Mar. & Apr. & $\begin{array}{c}\text { Total from } \\
\text { May } 23,1910, \text { to } \\
\text { May } 1,1911 .\end{array}$ & $\begin{array}{l}\text { Total from } \\
\text { Oct. } 1,1910, \text { to } \\
\text { May } 1,1911 .\end{array}$ \\
\hline 4,8 & None & 48.8 & 25.9 & 1,1 & 0.1 & 45.2 & 31.0 & 90.3 & 73.1 & 199.6 & 14.0 & 156.0 & 76.6 & 761.7 & 640.6 \\
\hline $5,7,9$ & Maize & 44.6 & 24.3 & 0.8 & 0.0 & 0.6 & 0.1 & 0.0 & 4.8 & 176.9 & 9.0 & 172.6 & 84.5 & 518.2 & 447.9 \\
\hline 10 & Oats & 50.1 & 24.0 & 0.2 & 0.2 & 0.0 & 0.0 & 6.0 & 52.7 & 149.3 & 6.0 & 172.3 & 105.4 & 566.2 & 491.7 \\
\hline
\end{tabular}

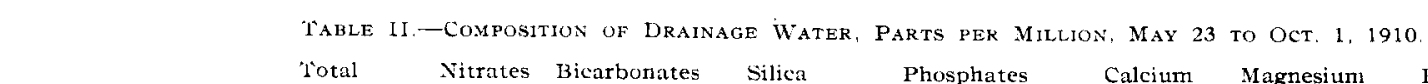

\begin{tabular}{|c|c|c|c|c|c|c|c|c|c|c|}
\hline rank Nos & Crop. & $\begin{array}{l}\text { l'otal } \\
\text { solids. }\end{array}$ & $\begin{array}{l}\text { Nitrates } \\
\left(\mathrm{NO}_{4}\right)\end{array}$ & $\begin{array}{c}\text { Bicarbonates } \\
\left(\mathrm{HCO}_{33}\right)\end{array}$ & $\begin{array}{l}\text { Silica } \\
\left(\mathrm{SiO}_{2}\right) \text {. }\end{array}$ & $\begin{array}{c}\text { Phosphates } \\
\left(\mathrm{PO}_{4}\right) \text {. }\end{array}$ & $\begin{array}{l}\text { Calcium } \\
\text { (Ca). }\end{array}$ & $\begin{array}{l}\text { Magnesiunı } \\
(\mathrm{Mg})\end{array}$ & $\begin{array}{l}\text { Potassium } \\
\text { (K) }\end{array}$ & $\begin{array}{l}\text { Sodium } \\
\text { (Na). }\end{array}$ \\
\hline $2,4,8$ & None & 606 & 73.7 & 372 & 8.9 & trace & 97.9 & 15.9 & 2.2 & 29.9 \\
\hline $3,5,7,9$ & Maize & 389 & 31.9 & 286 & 7.7 & trace & 71.7 & 18.0 & 1.1 & 15.3 \\
\hline 6,10 & Oats & 430 & 45.6 & 255 & 9.6 & trace & 80.9 & 19.1 & 1.2 & 14.2 \\
\hline
\end{tabular}

$\begin{array}{cccc}\text { TABLE } & \text { III.-COMPOSITION OF DRANAGE } & \text { WATER, } \\ \text { '́otal } & \text { Nitrates } & \text { Bicarbonates } & \text { Silica } \\ \text { solids. } & \left(\mathrm{NO}_{3}\right) & \left(\mathrm{HCO}_{3}\right) & \left(\mathrm{SiO}_{2}\right) \\ 618 & 136.0 & 256.0 & 6.4 \\ 264 & 14.6 & 181.0 & 4.8 \\ 271 & 14.6 & 192.0 & 4.6\end{array}$

$\begin{array}{ll}\text { Crop } \\ 2,4,8 & \text { None }\end{array}$

3. 5.7.9 Maize

6. 10 Oats

ured each month. An aliquot portion of the drainage water was removed from the receptacles from time to time for analysis. Samples representing the flow between May 23 and October I, I9Io, were analyzed

Science, N.S., 29, 621-3.

\begin{tabular}{|c|c|c|c|c|}
\hline $\begin{array}{c}\text { Phosphates } \\
\qquad\left(\mathrm{PO}_{4}\right) .\end{array}$ & $\begin{array}{c}\text { Calcium } \\
\text { (Ca) }\end{array}$ & $\begin{array}{c}\text { Magnesium } \\
\text { (Mg) }\end{array}$ & $\begin{array}{l}\text { Potassium } \\
\text { (K). }\end{array}$ & $\begin{array}{l}\text { Sodium } \\
(\mathrm{Na})\end{array}$ \\
\hline trace & 96.8 & 18.7 & 2.6 & 25.8 \\
\hline trace & 52.9 & 8.4 & 2,2 & 21.1 \\
\hline trace & 52.1 & 8.8 & 4.0 & 17.4 \\
\hline
\end{tabular}

January the unplanted tanks gave a much greater flow.

The composition of the drainage water in parts per million is stated in Tables II and III. The unplanted tanks show quite a constant density of 